\title{
ECOLOGICAL DISHARMONY AS THE SIN AGAINST THE SPIRIT
}

\author{
David T Williams \\ Centre for Theology and Religion \\ University of Fort Hare
}

\begin{abstract}
Although it is widely accepted that human activity is the cause of many of the ecological problems that are becoming increasingly evident, such activity is generally not really considered as morally wrong. Even less, although it may be seen as damaging a creation originally made good, is it seen as a sin against God. However, sin against the environment is certainly serious, and can even be seen as a sin against the Spirit. This is because the Spirit may be seen as the source of the harmony that is characteristic of biodiversity, and related to this, the source of the inter-relatedness within every organism that is the essence of life. The possibility is that extinction of species will continue, and even that life itself will end. This would indeed be a sin against the Spirit, a sin described appropriately in the Bible as 'mortal' (1 Jn. 5:16). It is a negation of the human role in the creation as in imago Dei. Hope lies in that while sin against the Spirit is unforgivable (e.g. Matt 12:32), this refers not to an isolated fault but an ongoing persistent attitude, which then can be reversed, motivating willingness to act as in priestly capacity as agents of the Spirit to give environmental healing. Just as physical healing in the body, this is a restoration of the harmony intended by the Spirit, and is often by the application of the laws that are part of the created order. As with sanctification, this is a foretaste of the perfection that God promises in the creation of a new environment.
\end{abstract}

Key Words: Unforgivable Sin; Image of God; Ecology; Holy Spirit; Stewardship

\section{Introduction}

Especially in the light of the offer of salvation simply on the basis of faith, the words of Jesus that there is a sin which is unforgivable (Matt. 12:32, Mk. 3:28, Lk. 12:10), are extremely striking. Cole (1961:85) says that although the passage contains one of the greatest promises, that of the breadth of forgiveness, it has one of the most solemn pronouncements in the New Testament. Marshall (1978:516) notes that the Markan version, which he feels is the original (1978:518), has the emphatic "truly I say to you". It has therefore generated a lot of discussion, also particularly due to a fear of some that they may have committed such a sin. Here it is usually said that any concern that a person has committed such a sin is actually proof that they have not (Grudem 1994:509, Berkhof 1958:254).

But what is this terrible sin? It is often said that the unforgivable sin is a refusal to accept the offer of life through Jesus, and indeed, as salvation is given through this acceptance, such a sin is indeed mortal. However, it must be observed that this explanation is not entirely consonant with the explanation that Jesus gave (Grudem 1994:507). In the gospel account the sin is committed by the Pharisees, not the man who was sick. 
Jesus himself indicated that the sin was attributing one of his works, done in the power of the Spirit (Erickson 1998:691), to the devil. The unforgivable sin is then a lack of recognition of the work of the Spirit, in that case the assertion that the healing of the blind and dumb demoniac was through devilish activity. It is here that blasphemy lies. Although Marshall (1978:517) says that to 'speak a word against' (Lk. 12:10) is a Semitism for 'curse', this is even more serious. .Witherington (2006:247) points out that in early Judaism, deliberate blasphemy is often seen as unforgivable. This is "the conscious and wicked rejection of the saving power and grace of God" (Beyer, in Marshall 1978:517).

The gospel utterance is perhaps the most dramatic, but there are other references to an unforgivable sin, notably in Hebrews 6:4 and 10:26-9, also linked to the Holy Spirit. Again, evidence of concern would perhaps be evidence that this sin is not in fact being committed. 1 John 5:16 also speaks of a 'mortal' sin, but there is no explicit link with the Spirit. Stott (1964:188) does identify it with the sin against the Spirit; however, he doubts that the sin can be apostasy. Grudem (1994:507) also feels that apostasy is not consistent with the passage.

Unforgivable sin can also be committed in other contexts where the Spirit acts. Is it not a sin against the Spirit to fail to recognize his action in the world, instead attributing what happens to chance or plain necessity? Failing to acknowledge the role of the Spirit in the created order is a sharing in the condemnation of the words of the Pharisees. In this case, I wonder if this sin is actually very widespread, for in the modern world, and even in the Church, there is a widespread lack of recognition of the action of the Spirit, and especially in the creation as a whole. While this does not go to the lengths of attributing creation to the devil, and not be exactly the sin against the Spirit, it must nevertheless be a serious matter to fail to recognize God's Spirit in the world.

Is this not actually the same as the attitude of many today, that it is possible to save the planet by human action alone? It may be observed here that the essence of Pharisaism was a belief that they were able to save themselves, that grace was not actually necessary, effectively that there was no need for the action of the Spirit. Of course here it must quickly be said that it is wrong to swing to the other extreme and be quietist, denying the need of any action on the part of people.

It would surely be even more serious to act against the work of the Spirit. In the New Testament case, this would be refusing to permit the healing of the man. In the light of Paul's assertion that the body is the Temple of the Spirit (1 Cor. 7:18), such a sin is against the Spirit. In the ecological case, this is the disrupting of the order in the creation that was produced by the Spirit. Regenstein (1991:16) exclaims that there can hardly be a greater sin! He cites the Lutheran Sittler, "reason says that destroying clean air is impracticable, faith ought to say it is blasphemous" (1991:154). God's purpose for the demoniac was full health, which the Pharisees threatened to subvert. Likewise his intention for the world is its full health. God's purpose is harmonious life. Particularly in a New Testament context, sin is a lack of conformity to the Spirit. The Hebrew word chet and the Greek hamartia both imply missing the mark, so failing to achieve the desired purpose.

Although the situation has changed to an extent in recent decades, it is sad to observe how little real ecological concern is actually present, even in a Church which purports to acknowledge that all is from God, and moreover usually asserts that God's action is essential for its continuance. This must be placed, very significantly, in the context that he has given to people both rights over the creation and the duty of caring for it. This latter is 

commonly called the dominion mandate, often linked to humanity being in imago Dei (Gen 1:26).

Certainly there is a need for better relating to the inanimate environment. Loader (1987:6) says that ecology is of 'vital' concern; his choice of word is because it affects human life (Latin: vita). But for him it is not just the self-interest for human survival that is the normal concern, as in much environmentalism, but relates to the inner, spiritual life. Osborn (1993:131) points out that much secular environmentalism is anthropocentric. Nevertheless, a better environment, and a better relating to it, will be good for human life, indeed enhancing a real humanity. Sin affects the environment, and the environment affects humanity (Gnanakan 1999:62). Birch, Eakin \& McDaniel (1990:2) point out that justice and correct inter-personal relationships demand a correct attitude to the environment; exploiting the environment exploits the poor who depend on it. The significance of anything lies in its connection to other things (Weaver 1999:137). Being for the environment is being for human life. Loader (1987:14) comments that much environmentalism is antihuman, seeing people as the cause of the problem, yet ultimately the action is pro-human, recognizing human dependence on a healthy environment for survival!

The lack of ecological concern, and of the gravity of this sin, must of course be seen in the context of the seriousness of the issues involved. Perhaps we treat the issues lightly as they do not seem to have any immediate impact upon us. But does the lack of immediacy blunt the view of the seriousness of the issue? Even if the demoniac was not immediately threatened with death, the sin was still described as unforgivable. In fact, ecological sin does have the capacity to destroy all life, not just that of some individuals. Even if ecological damage is unlikely to affect our life too much, it may be very serious for our descendents. The expression in Mark is guilt of an 'eternal sin'; even if it is not the main meaning, it may be noted that certainly ecological damage is often permanent. Matthew speaks of the impossibility of forgiveness 'in this age'. It may just be noted that we tend to spiritualise and generally put the effects of sin only in the future, if at all.

\section{Vinculum Amoris}

The demoniac was unable to relate adequately to others. Demons, as all evil, spoil relationships. Ironically, the Pharisees were betraying an essential lack of relationship with the man, not seeking his well-being, and also with Jesus, who desired his health. But afterwards, through his healing, the man was able to relate in a better way, particularly to other people, as he could then see and speak. The healing of the man thus had the effect of improving his quality of life. Physically, the healing was effectively an improved interrelating of the organs of his body. Our ecological ill-health lies in our lack of relating properly to the world, and our quality of life is threatened. Sin results in broken relationships (Weaver 1999:129). Any sin affects the entire context of life, including the ecological. After all, "God may use the environment as a scourge of judgment upon human sin” (McPherson 1986:238).

Reference to relationship immediately draws attention to the Spirit as the author of life and of health, both of the individual, and more widely, in particular, in the natural order. This is because the interaction of biodiversity may also be seen as a work of the Spirit. The role of the Spirit in the world may be seen as essential to its existence (Williams 2014). Among many others, Moltmann (1985:14) affirms the Spirit's role in the creation as its "total cohesion, its structure, its information, its energy". "Everything exists ... in the cosmic interrelations of the divine Spirit" (Moltmann 1988:10). For Einstein, God was 
manifested in the laws of nature (Weaver 1999:146). The Spirit gives the inter-relationships fundamental to existence, hence it can be seen as the immanent presence of God in it. He gives order and harmony, just as he relates the Trinitarian Persons in perichōrēsis. Conradie (2005:51) can speak of an 'ecological Trinitarian communion'. The creation reflects the Trinity, not surprisingly, as he made it. Moltmann therefore advocates perichoretic thinking in respect of the environment (in Bergmann 2005:ix). One key parallel is that the creation is a web of incredible diversity - a diversity in inter-relationship. (Incidentally here, many have seen reflections of the Trinity in creation, commonly called the vestigia Trinitatis.) Just as the relating in the Trinity rests on the active presence of the Spirit, so does inter-relating in the world. Harmony is far from natural, as we are reminded by the second law of thermodynamics. It is disharmony that comes naturally.

While creation of the material was through the second Person (1 Cor. 8:6), it was the Spirit who produced the interactions and order of what had been created by the word. Crudely, words are ineffective without breath. The rationality and organization that are essential to existence, so also for creation, are given by the Spirit. The creative act, characteristic of the second Person, is made effective by the third, the 'executive' member of the Trinity. This twofoldness can be seen, in particular, in Genesis 2, the breath into the clay figure was a second creative act and gave it life. Likewise two actions are present in the raising of the slain host in the valley of dry bones (Ez. 37). Then the work of the Spirit is also essential in salvation, as in re-creation, applying the work of the cross. Macquarrie (1971:8) insists that we need to move from the traditional monarchic view of God, as in creation, towards an organic model. In fact, both aspects together better reflect the Christian view of a theistic deity.

The sin against the Spirit is then a sin against relationship. In this case, disrupting the harmony of the natural order, is a sin against the Spirit. Especially if the present diversity is understood as the result of the evolution made possible by the order which is from the immanent presence of the Spirit, and not from a direct creation by the Son, then ecological damage is indeed a sin against the Spirit. Our action in the world should be such as is consistent with the Spirit, i.e., in harmony with the world. Regenstein (1991) recounts many instances of a relationship of harmony with the creation, such as, of course, by Francis of Assisi (1991:65f). Osborn (1993:157) comments that his respect for creation emerged gradually out of his reverence for Christ.

If the interaction is damaged, then there is a loss of purpose, just as any machine cannot do what it was made for if it is not working properly. Such a loss of purpose may also be related to the Spirit, as when a person is 'dispirited'. If the creation is Spirit-less, the whole creation is subjected to futility (Rom 8:20), thus to lack of purpose. Conradie (2005:73) suggests 'senselessness'. Incidentally, a sense of purpose is an indication that there is no determinism. Even if harmony is due to the Spirit, there can be a diversity of possibilities of harmony.

It must be pointed out that this is not the same as seeing the world as possessing some form of soul, which would indeed render ecological damage in a most serious light. Even though the earth has been viewed as being alive, as in 'Gaia' theology (Russell 1994:107f, Weaver 1999:121f), and currently in versions of the 'New Age' movement (cf. Russell 1994:94f), it is most commonly seen today in mechanistic terms (Bergmann 2005:24). Descartes saw animal life in this way (Regenstein 1991:78). I would indeed see the essence of life simply in interaction (Williams 2002:271f). This means that the Spirit is not present 
in a living being in any ontological sense, but as providing the laws and means of that interaction.

\section{Persistent Attitude}

Understanding the unforgivable sin in relational terms also suggests that it is not simply an isolated act, but a long-term attitude. Likewise, ecological damage is more often long-term than a result of single actions.

The incident of the demoniac is of course not an isolated case; the gospels contain many similar confrontations with the Pharisees. Hoekema (1986:183) points out that the tense in Mark 3:30 is imperfect; the Pharisees went on saying what they did. The Pharisees were persistently refusing to listen to Jesus, rejecting a harmonious relation with him. The problem was continuous, so long-term. Similarly, 1 John 1:8 and 3:6 do not deny the possibility of isolated sin by Christians, but refer to persistent disobedience. In the same way, Stephen, at his martyrdom, condemned his accusers as always resisting the Spirit (Acts 7:51). It must just be observed here that the action of the Spirit is generally long-term; Ephesians 5:18 commands Christians to be filled with the Spirit, where the tense indicates a continuous and repeated action.

The sin against the Spirit is the result of a deliberate attitude, such as in Romans 1:18f where there is wilful ignorance, resulting in God giving up on the sinner, allowing the effect of sin to go to its conclusion. As God respects human free will, he does not simply override human action. As God generally does not intervene, in general, the effects of these sins occur seemingly inevitably. If a forest is burnt, animals and plants die and quite possibly erosion and permanent damage follows. If rhinos are slaughtered for their horns, the eventual result can well be their extinction. Even if we feel that God should stop these things, in general he does not. Thus the effects of sin stand. His preference is to initiate an alternative, effectively an escape plan, which is what Christ came to enact. This also implies the possibility of human action in overcoming sin, such as in the environment.

Morris (1974:211) sees the nature of the unforgivable sin in just such terms. Cole (1961:85) interprets it as that of wilful blindness. Stott (1964:187) also draws attention to the Old Testament division between accidental and presumptuous sins, the latter being unforgivable. Such a sin is so serious that it affects the whole person. It affects the totality of relationships, which include that to the environment. Such a person has no capacity to repent and believe.

Are we likewise guilty of persistently refusing to hear the words of the Spirit as regards his work in creation? Are we ignoring ecological warnings? Although there is increasing evidence of the effect of human action on the environment, and a growing appreciation of the fact that life is dependent on ecological biodiversity, these are likewise often ignored. As is usually the case with sin, there is an element of irrationality. It is senseless (Conradie 2005:197).

\section{Perversion of the Mind}

The location of the sin thus lies in the mind, and the solution is only possible in the transformation of the mind. Jesus' first recorded message was of the need to repent (Mk. 1:15), the word being metanoia, a change in mind.

Indeed, the focus in the 'blasphemy' passages is not on action, but on attitude. In the synoptic the sin is blasphemy, speaking against the Spirit, but no sinful action is actually 
being done. The healing was not prevented nor denied. However, the attitude is significant. The condemnation fell not on actually causing disharmony, but on refusing to accept that the healing was due to the Spirit. The sin that is condemned is a lack of recognition of the role of the Spirit. For Berkhof (1958:253) the sin is the rejection of the testimony of the Holy Spirit. This is important, for if the means of healing was not recognised, it would not be used, so damage would be allowed to continue, and the demoniac would not have been healed. The attitude of the Pharisees, of rejection of the means and of the healer, could hardly lead to healing! Jesus himself remarked that intention is as serious as the act of sin itself (Matt. 5:27f). Notably, salvation is by faith not action, reflecting the fact that the essence of sin lies in attitude not act. Faith, in essence, is relational. Insofar as healing is essentially a re-creation, it must be noted that creation was achieved not by active forming, but by words.

Certainly thought can easily slide into act, and similarly, failing to see the importance of the Spirit in ecology weakens concern for it. Regenstein (1991:136) cites Rossi, who rejecting the opinion of Lynn White (1967), felt that "it was only when the West 'liberated' itself from Christianity ... that the door was opened for the ecological disasters of the present day". Ecologically, if the sin is a lack of recognition of the role of the Spirit in giving order to creation, then its healing is not likely. At the same time, denying God's action and concern for the environment demotivates the action of Christians as Christians. Bergmann (2005:3) comments that "an ecological theology can expect great things if it will but rediscover how to speak about the Holy Spirit".

As well as producing communion, the Spirit enhances awareness (Taylor 1972:200). We relate to the world by sense, hence the Spirit enhances sense. Naturally this includes wisdom as the appreciation of inter-relatedness. This is connected with the Spirit (Is 11:2, 1 Cor. 12:8). Insofar as the Spirit enhances order, he gives an appreciation of that order, leading to proficiency and development in science. Calvin taught that all ability in arts or science, that is, talent, is from the Spirit, so any truth manifesting in the human mind, is from the Spirit as the sole fountain of truth (cited in Hoekema 1986:189). Of course, even if all truth, and all beauty, do come ultimately from God, no matter by whom they are expressed, it does not mean that God's Spirit directly causes them, or that they are a sign of his presence (Ferguson 1996:246). This is an aspect of 'common grace'.

Action can only come about as a result of conviction, a conviction that healing is both right and possible. Of course, fundamental to this is the transformation of the mind, so of attitudes. While the action of the Spirit was essential in the establishment of the world in creation, this transformation is enabled in re-creation, essentially a spiritual matter (Rom 12:1-3). On the one hand, sin affects the interaction of the body, specifically of the mind, resulting in a loss of appreciation of the consequence of action. On the other, as sanctification is a transformation of the mind, "in its fullest sense it involves the redirection of all of life" (Hoekema 1986:88). Moltmann (1988:11) writes that one should no longer want to know in order to dominate, but to participate. The tragedy is that this is not happening, as the Spirit is

\section{Imago Dei}

Seeing the possibility of committing the unforgivable sin in a failure to recognize the action of the Spirit in the creation naturally directs attention to the Biblical account of creation. Gnanakan (1999:48) asserts that the ecological crisis is inexplicable without reference to the Biblical account of sin. It would seem that the primal sin (Gen. 3) was indeed unfor- 
givable. The order that the Spirit gave manifested in the relationship by which humanity is in the image of God, a relationship disrupted by the first sin. Ironically, even recognition of humanity's creation in imago Dei has often been lifted out of its context in creation, and seen as having a primary reference to a relation to God (Santmire 1985:5). Osborn (1993:132) points out that although Biblical references to the imago Dei are few, they correlate with some of the most significant passages about the non-human creation.

It is noteworthy that the description of the primal sin included three aspects in its results. All relate to the Spirit, for all indicate a loss of harmony, damage to the original inter-relationships. All have ecological implications.

The three aspects are those which are currently the preferred understandings of the meaning of humanity in imago Dei. They are perversions of the image which result from the desire to be like God, so to damage the correct relationship between God and people as generated by the Spirit. Even though substantialist interpretations of the image were accepted for several centuries, in recent times the relational understandings have prevailed. These are the dominion of humanity over the material world, the sexual nature of humanity, and, I would add, the existence of life itself (Williams 2011:314f). Sin manifests in these three relationships. Not that the change of emphasis is fundamental; the loss of the image in sin has commonly been linked to a loss of full rationality, hence to of wrong attitudes, a perversion at the heart of the meaning of the unforgivable sin.

Understood in relational terms, the primal sin is a direct affront to the very nature of humanity, and to God himself, the disruption of Spirit-given harmony. Sin is against the nature of God, whose essence is harmony in perichōrēsis. However, Santmire (1985:9) insists that there are three inter-relating entities, God, humanity and the world, not just the first two. The essence of humanity is being in a three-fold relationship, the original harmony in each is affected by sin. Sin affects the relations to God (Gen. 3), to people (Gen. 4), and to the world (Gen 6) (Conradie 2005:194). These three fundamental relationships, which have tended to become dualisms in Western theology, must be addressed simultaneously, as they inter-relate (Daly 1990:107). Here the Spirit relates all three. Sin affects the relationship to the created order; the image passage puts people in the context of other life on the sixth day, clearly reflecting their place as a part of biodiversity. Ecological sin continues to damage the harmony in creation, the perichōrēsis of interaction in diversity.

Firstly, there was death, due to a loss of the Spirit-enabled relationship with God, and not accepting his life. There was no longer an effective relationship with the lifegiver. In terms of Genesis 3, there was lack of access to the tree of life. This death did not occur immediately, but was the culmination, perhaps better as the final event in the process, of the consequent deterioration in the bodies of the couple, and in all their descendants. Similarly, death in an ecological sense is due to a lack of dynamic interaction with the source of life. The Spirit does not actively sustain the world in a panentheistic sense, rather by providing the framework in which the interaction that is life can occur, but without actual interaction with its source, death became inevitable. It was not an immediate event, but a long process. However, the fact that death is a process does not mean that it is simply reversible. There is ongoing extinction of species, even if there is some hope of re-creation from DNA. In the case of people, as well, there is a possibility of some reversal due to the gift of eternal life, which has results in the present. This is not to say that death is not a part of the original creation. It is an inherent aspect of creation, a part of the evolutionary process. People 
naturally also die. Eternal life is not inherent to humanity but is an endowment. In the Genesis story it is portrayed as only possible due to access to the tree of life.

It may be observed that this suggests a traducianist anthropology that life is not given by an immediate creative act of God, but is naturally generated from life itself as part of the created order. The implication concerns the effect of action in the present upon future generations. Sin is a rejection of the effective continuation of the means of life. The gift of life is perverted when action damages the interactions necessary for life, for example in clearing the rainforests.

The second effect of sin on the imago Dei was that human relationships were distorted, leaving a lack of equality between the sexes and so disharmony. The full perichoretic interaction of equals was perverted into dominance; "your desire will be for your husband" (Gen. 3:16). Reproduction was also affected as there was pain in childbirth. This can also be seen as a lack of harmony. The ongoing effect of this was that sexuality was perverted and procreation became incompatible with the environment. The effect of sin in ecological disharmony can only be expected to produce unpleasant effects. The result of this is not the filling of the earth in terms of the original mandate of Genesis 1, but of excessive population resulting in non-sustainability. Moltmann (1988:18) says that instead of humanity providing a key role in the functioning of the earth, it is rather a 'gigantic cancerous growth'.

The distortion of human relationships has other effects as well, because the structures of human society are damaged. Barth's suggestion of the meaning of the image does not pertain simply to the sexuality of man and woman, but embraces relation. Barth (1958:195) sees the image in "... confrontation, in the juxtaposition and conjunction of man and man which is that of male and female". Thus between God and people there is not an analogy of being (analogia entis), but of relation (analogia relationis) (Hoekema 1986:50). Liberation theology has drawn attention to structural sin, which is located not in positive acts but in organisation, so in interaction. It has resulted in extreme inequality in society, in oppression and poverty and therefore animosity and even conflict. This naturally also has definite ecological effects, for example in pollution which is done without the concern for others that harmony would produce, and in rapacious exploitation of resources, usually for the benefit of some and probably harm to others.

On the one hand, relation to the environment is ignored and the responsibility is not exercised, but on the other, the third effect of sin, is that dominion has been perverted to excessive domination rather than serving. Ironically, the Christian understanding of dominion has even been used to justify what can only be seen as ecological sin (cf. White 1967:1205). Perhaps this should not be surprising as the attitude of the Pharisees was from religious roots! Dominion is perverted when the relationship with the creation is not consistent with the relation to God. In particular, dominion should not be seen as that of absolute right, but that of a steward, and including answerability. It may be observed that these perversions reflect Trinitarian heresy, denial of the inner Trinitarian relation enabled by the Spirit, either of tritheism, where the relationship is not present, or of the domination of subordination. Conradie (2005:53) points out the danger of an 'anthropological Arianism' in an incorrect view of the role of dominion. Osborn (1993:139) points out that human dominion in the image of God should be modelled on that of God, which is in terms of love.

In perversion, the interaction with the material world became arduous. Labour became hard and the earth did not easily yield what was desired, and actually gave what was not 


\section{Reflections on the Theological Discourse of Climate Change in the Household of God 9}

desired (Gen. 3:18). This is not surprising; while the Spirit is present as the originator of the interactions of the planet, the direct action falls away, so that the interrelationships are only natural. This means that processes became inefficient, so work is wasteful and harder. It is even possible to see the intrusion of the disruption of the demonic. An example of this is the sower of the tares in Jesus' parable (Matt. 13:24f). Notably, in the other little parable associated with the unforgivable sin (Matt. 12:29), the effect of evil is prevented by the action of a strong protector. With God's active presence, evil is unable to act. As often seen in South Africa today, static and inert protection such as walls needs the provision of active and live guards to supplement it.

\section{Agents of the Spirit}

The presence of the Spirit of God in the world is not limited to his provision of the order underpinning existence, but naturally continues in healing of the damage that has been done in sin. It is this that is done through the action of human beings in imago Dei, and their refusal to do so must be culpable.

In fact, the sin of the Pharisees was a lack of mercy, for which a lack of mercy to them would be appropriate. People are called upon to reflect the attitude of God, which as Regenstein (1991:40) points out, includes the environment.

Here it may be noted that the context of Jesus' words in respect of the unforgivable sin in the first two gospels is that of healing. This is fundamentally a restoration of harmony in the body, which was inadequate either from birth or due to disease. The Spirit generates harmony. The healing of the demoniac can be attributed to the Spirit because it was fundamental to his activity of generating relationships to give a restoration of harmony for the demoniac.

Jesus applied the power of the Spirit in the restoration of the health of the demoniac. A small part of the creation had its disruption reversed. In this, God was glorified, as there was greater conformity to his purpose. But just as the Spirit did this through the agency of Jesus, so he can also do similar works through the agency of God's people, who are the 'body of Christ'. As Jesus said in another context of those who believe in him, "greater works than these will he do" (Jn. 14:12).

While an aspect of the Spirit's upholding of creation is human action in fulfilling the dominion mandate, this has been perverted. It is typical of the work of God and so of the Spirit that action is generally done by agents, but if people do not know this, or do not accept it, then this work is not likely to be done. People are called to act as priests for the work in the creation, as channels for harmony, as with healing, but may well not recognize this. However, Gnanakan (1999:179) points out that a renewed image includes a sense of responsibility. Here Kehm (1992) argues that the well-accepted picture of dominion as stewardship needs to be supplemented by that of a priestly role.

Van Huyssteen (2006:148) refers to the view of Philip Hefner that people are 'created co-creators', "whose task and purpose is the 'stretching and enabling' of the systems of nature so that they can participate in God's purposes for the world". The focus in the understanding of the imago Dei has shifted from seeking how people are different from the non-human, which is actually very hard to see, to the uniqueness of their role (Osborn 1993:133). Likewise Middleton (2005:89), observing that God both rules and creates cosmic structure, says that people creatively form and fill the world and so reflect the twofold role of God (in Van Huyssteen 2006:157). This reflects Augustine, who felt that divine governance was by his governance of other creatures (Santmire 1985:63). 
Of course, in the modern context, even if healing as Jesus did remains a possibility and indeed does occur, we tend to use the methods of orthodox medicine through the agency of trained medical practitioners. This is actually not fundamentally different, as what is being done is through recognition of cause and effect in the world, which was placed there by the Spirit. Whenever a drug works, it is because the body obeys a biological law, a manifestation of the orderliness that the Spirit gave. We often recognize the effect, but not the underlying cause. The fundamental difference is often in the time-frame.

Action in the healing of the environment can follow a similar principle. On the one hand, recognising the Spirit given order in the world, it is possible to act in conformity with it to enhance harmony. We water our plants to encourage their growth. Indeed, the usual way by which God acts in the world is by human action, fulfilling their Spirit-given role as priests. People are the instruments for the redemption of creation (Sauer 1967:97). Kehm (1992:130) indeed relates this to the unique nature of humanity as spiritual and physical. This is part of being in imago Dei. In his discussion of the 'mortal sin' in 1 John 5:16, Stott (1964:189) notes that it is life that is given in response to prayer, an encouragement to pray for the environment before it is too late and the sin does become 'mortal'. Pinnock (1996:54) cites Kuyper, who he says follows Calvin, saying that the Spirit exercises a steady influence on creation, leading it to its destiny, giving gifts and talents to humanity. Just as Jesus' healing of the demoniac followed from his anointing with the Spirit for his ministry (Lk. 4:18), enabling him to fulfil the role for which he came, so human action for the environment follows from their becoming more conformed to the image of God, accepting the three aspects of the image. In all three, the Spirit works through human agency, which affects the environment. As Thielicke says, humanity possesses the image in hope (Conradie 2005:195).

Firstly, the exercise of dominion is through stewardship (Hall 1986). Here a steward is one who acts on behalf of the master. When Jesus referred to the unforgivable sin, the issue was that he was accused of serving a different master, the devil instead of God. Here, effective dominion is not simply from human action, but through the action of the Spirit (cf. Zech. 4:6, Hag. 2:5). Secondly, just as salvation comes from the interactive work of the three Persons, so salvation of the environment can only come from a concerted human action, as it demands more than the action of isolated individuals, but from society as a whole. Naturally the action of the Spirit as vinculum amoris is fundamental to this. Thirdly, effect in the environment follows from the dynamic of the gift of new life. Part of this is that new life in a person results in sanctification, a change in a person, particularly in the mind. A sanctified life relates more naturally to other people, and also to the environment. However there is also a direct effect, as when the touch of Jesus healed the woman with the issue of blood (Lk. 8:43). This has a wider effect than in a person, such as in the harmony with nature evidenced in such as Francis of Assisi. Just as the new life in a person positively benefits those in relation to him or her, it affects also the wider nexus of relationships, which would include that with the environment.

It is, of course, also not out of the question to ask God to intervene directly in the world, definitely a priestly action. An example of the latter is praying for rain in a time of drought. This is not life-giving as such, but affects the environment so that the natural processes of nature can flourish. 


\section{Recreating to Total Harmony}

Despite growing concern and action for the environment, the situation is far from encouraging. Nevertheless, there is hope, which is indeed anticipated in the Bible, such as in Revelation 21. Gregory of Nazianzus gives reassurance in his belief that God will fulfil what he has begun (Bergmann 2005:xi). Regenstein (1991:22) draws attention to some Biblical promises of future harmony (e.g. Hos. 2:18f, Jb. 5:23, Is. 11:6-8). This means a fulfilment of all the relationships, living as originally intended in harmony with God, other people and environment. This includes the last aspect, as the dominion mandate is then obeyed properly. Jesus, as image, came to reconcile 'all things,' including the physical universe, to himself, so to restore all relationships (McConnell 2006:124). Salvation includes the material. Sittler writes that "salvation is an ecological word in the sense that it is the restoration of a right relation which has been corrupted" (Conradie 2005:201).

The Spirit will perfect creation (Pinnock 1996:61). Indeed, insofar as the creation was spoilt to an extent by sin, its purpose could be restored in re-creation. Through the Spirit, the creation moves towards its re-creation (Pinnock 1996:58). Pinnock (1996:49) cites Pope John Paul II with approval; for him, the Spirit is "the breath of life which causes all creation, all history, to flow together to its ultimate end, in the infinite ocean of God". Insofar as 'spirit' may be related to motivation and purpose, the filling of the world by the Spirit would mean that the purpose in creating could be enhanced, that the spirit, or purpose, in creation could be more abundantly fulfilled.

As the Heidelberg Catechism teaches, believers will reign, living on a renewed earth (Hoekema 1986:94). The final state is not just 'spiritual' as that is only part of what being in the image of God means, but on the earth in spiritual bodies (1 Cor. 15:44). The Christian expectation is of the resurrection of the body. Dominion is then also over death (Grenz 2001:235), of course sharing in Christ's victory.

Here the measure of harmony possible in the present is an anticipatory 'first-fruit' of the state of the renewed creation. As typical of his workings, the action of the Spirit in the present is a first-fruit of the future fulfilment (Rom. 8:23). Although the idea is usually applied to the individual, in this case the first-fruits are evidenced also in environment, where human action can have beneficial ecological effects.

Ultimate hope lies in a recreation, but notably the previous life continues and works through to its logical conclusion, albeit affected by the presence of the new, with which it inter-relates. Eventually, the old life dies and life continues, but in anticipation of a resurrection. New life is present, but only partially, as a foretaste of the future. The same is true for the environment.

This does not just mean that the attitude to the present is one of resigned despair, simply waiting for God's future act. Christians have often, and justifiably, been accused of 'ecological quietism' (cf. Santmire 1985:1). Osborn (1993:147) points out that priesthood combines prayer and action. Here Marshall (1978:519) points out that the Lukan text of blasphemy against the Spirit is followed by a promise of the Spirit's guidance. Sensitivity to his leading will show what is to be done for the planet. While the fullness of salvation is only future (Rev. 21), the present can be changed in anticipation of that, and reflect the kind of life that the future will hold. It is done with the end in view (Osborn 1993:144). Just as with the individual in the process of sanctification, the old can be affected by recreated people as priests. 


\section{BIBLIOGRAPHY}

Barth, K 1958. Church Dogmatics Vol 3(1): the doctrine of creation. Edinburgh: T\&T Clark.

Bergmann, S 2005. Creation set free: the Spirit as liberator of nature.

Grand Rapids: Eerdmans.

Berkhof, L 1958. Systematic theology. London: Banner of Truth.

Birch, C, Eakin, W \& McDaniel, JB (eds.) 1990. Liberating life: contemporary approaches to ecological theology. Maryknoll, NY: Orbis.

Birch, C, Eakin, W \& McDaniel, JB 1990. Introduction. Birch, Eakin \& McDaniel (1990:1-5).

Cole, RA 1961. The gospel according to St. Mark: an introduction and commentary. London: Tyndale.

Conradie, EM 2005. An ecological Christian anthropology. Aldershot: Ashgate.

Daly, LK 1990. Ecofeminism, reverence for life, and feminist theological ethics.

Birch, Eakin \& McDaniel (1990:88-108).

Erickson, MJ 1998. Christian theology. $2^{\text {nd }}$ ed. Grand Rapids: Baker Academic.

Ferguson, SB 1996. The Holy Spirit. Downers Grove, Ill: InterVarsity.

Gnanakan, K 1999. God's world: Biblical insights for a theology of the environment. London: SPCK.

Grenz, SJ 2001. The social God and the relational self: a Trinitarian theology of the Imago Dei. Louisville: Westminster John Knox.

Grudem, W 1994. Systematic theology: an introduction to biblical doctrine. Leicester: Inter-Varsity/Grand Rapids: Zondervan.

Hall, DJ 1986. Imaging God: dominion as stewardship. Grand Rapids:

Eerdmans/New York: Friendship press for Commission on Stewardship, National Council of the Churches of Christ in the USA.

Hoekema, AA 1986. Created in God's image. Grand Rapids: Eerdmans/Exeter: Paternoster.

Kehm, GH 1992. Priest of creation. Horizons in Biblical theology 14(2):129-42.

Loader, JA 1987. Image and order: Old Testament perspectives on the ecological crisis. In Vorster, WS (ed.) Are we killing God's earth? Ecology and theology. Proceedings of the eleventh symposium of the Institute for Theological Research (UNISA) held at the University of South Africa in Pretoria on 2 and 3 September 1987. Pretoria: University of South Africa (6-28).

McConnell, W 2006. In His Image: a Christian's place in creation. Asia Journal of Theology 20(1):114-27.

McPherson, J 1986. Towards an Ecological Theology. Expository Times 97(8):236-40.

Macquarrie, J 1971. Creation and environment: the inaugural lecture at Oxford University. Expository Times 8:4-9.

Marshall, IH 1978. The Gospel of Luke: A Commentary on the Greek Text. Exeter: Paternoster. Middleton, J 2005. The liberating image: the Imago Dei in Genesis 1. Grand Rapids: Brazos.

Moltmann, J 1985. God in Creation: a New Theology of Creation and the Spirit of God:

The Gifford Lectures 1984-1985. San Francisco: Harper \& Row. 
http://scriptura.journals.ac.za

Reflections on the Theological Discourse of Climate Change in the Household of God 13

Moltmann, J 1988. The ecological crisis: peace with nature? Scottish Journal of Religious Studies 9 5-18.

Moltmann, J 1993. God in creation: a new theology of creation and the Spirit of God. The Gifford lectures 1984-1985. Minneapolis: Fortress.

Morris, L 1974. The gospel according to Luke: an introduction and commentary.

London: Inter-Varsity.

Osborn, L 1993. Guardians of creation: nature in theology and the Christian life. Leicester: Inter-Varsity (Apollos).

Pinnock, CH 1996. Flame of love: a theology of the Holy Spirit. Downers Grove, Ill: InterVarsity.

Regenstein, LG 1991. Replenish the earth: a history of organized religion's treatment of animals and nature - including the Bible's message of conservation and kindness to animals. London: SCM.

Russell, CA 1994. The earth, humanity and God: the Templeton lectures, Cambridge, 1993. London: UCL.

Santmire HP 1985. The travail of nature: the ambiguous ecological promise of Christian theology. Philadelphia: Fortress.

Sauer, E 1967. The king of the earth: the nobility of man according to the Bible and science. Exeter: Paternoster.

Stott, JRW 1964. The epistles of John: an introduction and commentary. London: Tyndale.

Taylor, JV 1972. The Go-between God: the Holy Spirit and the Christian mission. London: SCM.

van Huyssteen, JW 2006. Alone in the world? Human uniqueness in science and theology. Grand Rapids: Eerdmans.

Weaver, J 1999. Earthshaping earthkeeping: a doctrine of creation. London: SPCK (Lynx).

White, L Jr 1967. The historical roots of our ecologic crisis. Science 155(3767):1203-7.

Williams, DT 2002. What is life? Koers 67(3):271-82.

Williams, DT 2011. 'Unveiling' the understanding of the imago Dei. Scriptura 108:314-25.

Williams, DT 2014. The Spirit in creation. Scottish Journal of Theology 67(2) (forthcoming).

Witherington, B III 2006. Matthew. Macon, GA: Smyth \& Helwys. 